\title{
Host-microbial interactions in childhood atopy: toll- like receptor 4 (TLR4), CD14, and fecal Escherichia coli
}

Citation for published version (APA):

Penders, J., Thijs, C., Mommers, M., Stobberingh, E. E., Dompeling, E. D., Reijmerink, N. E., van den Brandt, P. A., Kerkhof, M., Koppelman, G. H., \& Postma, D. S. (2010). Host-microbial interactions in childhood atopy: toll-like receptor 4 (TLR4), CD14, and fecal Escherichia coli. Journal of Allergy and Clinical Immunology, 125(1), 231-236.e5. https://doi.org/10.1016/j.jaci.2009.10.011

Document status and date:

Published: 01/01/2010

DOI:

10.1016/j.jaci.2009.10.011

Document Version:

Publisher's PDF, also known as Version of record

Document license:

Taverne

Please check the document version of this publication:

- A submitted manuscript is the version of the article upon submission and before peer-review. There can be important differences between the submitted version and the official published version of record.

People interested in the research are advised to contact the author for the final version of the publication, or visit the DOI to the publisher's website.

- The final author version and the galley proof are versions of the publication after peer review.

- The final published version features the final layout of the paper including the volume, issue and page numbers.

Link to publication

\footnotetext{
General rights rights.

- You may freely distribute the URL identifying the publication in the public portal. please follow below link for the End User Agreement:

www.umlib.nl/taverne-license

Take down policy

If you believe that this document breaches copyright please contact us at:

repository@maastrichtuniversity.nl

providing details and we will investigate your claim.
}

Copyright and moral rights for the publications made accessible in the public portal are retained by the authors and/or other copyright owners and it is a condition of accessing publications that users recognise and abide by the legal requirements associated with these

- Users may download and print one copy of any publication from the public portal for the purpose of private study or research.

- You may not further distribute the material or use it for any profit-making activity or commercial gain

If the publication is distributed under the terms of Article $25 \mathrm{fa}$ of the Dutch Copyright Act, indicated by the "Taverne" license above, 


\title{
Host-microbial interactions in childhood atopy: Toll-like receptor 4 (TLR4), CD14, and fecal Escherichia coli
}

\author{
John Penders, PhD, , ${ }^{a}$ c Carel Thijs, MD, PhD, ${ }^{a}$ Monique Mommers, PhD, ${ }^{a}$ Ellen E. Stobberingh, $\mathrm{PhD},{ }^{\mathrm{c}}$ Edward \\ Dompeling, MD, PhD, ${ }^{d}$ Naomi E. Reijmerink, MD, ${ }^{\text {f,g }}$ Piet A. van den Brandt, PhD, ${ }^{b}$ Marjan Kerkhof, MD, PhD, ${ }^{h}$ \\ Gerard H. Koppelman, MD, PhD, ${ }^{e}$ and Dirkje S. Postma, MD, PhD ${ }^{g}$ Maastricht and Groningen, The Netherlands
}

Background: Perturbations in the gut microbiota have been linked to atopic diseases. However, the development of atopic diseases depends not only on environmental factors (like microbial stimulation) but also on genetic factors. It is likely that particularly gene-environmental interactions in early life determine the development of atopy.

ObjectiveWe examine the interaction between detection of fecal Escherichia coli and genetic variations in the CD14 and Toll-like receptor 4 (TLR4) genes in relation to atopic manifestations. Methods: Within the Child, Parent and Health: Lifestyle and Genetic Constitution (KOALA) Birth Cohort Study, fecal samples of 957 one-month-old infants were collected and quantitatively screened for $\boldsymbol{E}$ coli. Fourteen haplotype-tagging polymorphisms in the genes TLR4 and CD14 were genotyped in 681 of the 957 children. Atopic outcomes were parentally reported eczema in the first 2 years of life and clinically diagnosed eczema and allergic sensitization at age 2 years. Multiple logistic regression was used to evaluate a multiplicative model of interaction.

Results: Most of the single nucleotide polymorphisms (SNPs) showed no significant interaction with $E$ coli exposure for both eczema and allergic sensitization. A borderline significant multiplicative interaction was found between $E$ coli and the rs2569190 (CD14/-159) SNP regarding allergic sensitization. Furthermore, a statistically significant multiplicative interaction was found for the TLR4 SNP rs10759932 (P for interaction = .001). $E$ coli colonization was associated with a decreased risk of sensitization only in children with the rs10759932 TT genotype (adjusted odds ratio, $0.31 ; 95 \% \mathrm{CI}, 0.14-0.68$ ) and not in children with the minor $\mathrm{C}$ allele. This interaction remained statistically significant after controlling for multiple testing.

\footnotetext{
From ${ }^{a}$ the Department of Epidemiology, Nutrition and Toxicology Research Institute Maastricht and Care and Public Health Research Institute and ${ }^{\mathrm{b}}$ the Department of Epidemiology, Research Institute Growth and Development, Maastricht University; ${ }^{\text {'t }}$ the Department of Medical Microbiology and d the Department of Pediatric Pulmonology, University Hospital Maastricht; and ${ }^{\mathrm{e}}$ the Department of Pediatric Pulmonology and Pediatric Allergology, ${ }^{\mathrm{f}}$ Beatrix Children's Hospital, and, ${ }^{\mathrm{g}}$ the Department of Pulmonology, and ${ }^{\mathrm{h}}$ the Department of Epidemiology, University Medical Center Groningen, University of Groningen.

Supported by the Netherlands Asthma Foundation (grant no. 3.2.07.022) and The Netherlands Organisation for Health Research and Development (ZonMw; grant no. 912-03-031)

Disclosure of potential conflict of interest: C. Thijs receives research support from Paraclesus Spital Richterswil $(\mathrm{CH})$. The rest of the authors have declared that they have no conflict of interest.

Received for publication March 13, 2009; revised September 16, 2009; accepted for publication October 12, 2009.

Reprint requests: John Penders, $\mathrm{PhD}$, Department of Epidemiology, Maastricht University, PO Box 616, 6200 MD Maastricht, The Netherlands. E-mail: j.penders@epid. unimaas.nl.

$0091-6749 / \$ 36.00$

(C) 2010 American Academy of Allergy, Asthma \& Immunology

doi:10.1016/j.jaci.2009.10.011
}

Conclusion: The current study is the first to address the potential effect-modifying role of genetic variations in the relationship between the intestinal microbiota and allergy development. (J Allergy Clin Immunol 2010;125:231-6.)

Key words: Atopy, Toll-like receptor 4, CD14, gene-environment interaction, Escherichia coli, intestinal microbiota

The gut microbiota is a key source of microbially driven immune regulation and oral tolerance induction in early life. Perturbations in the gut microbiota may therefore be involved in the pathogenesis of atopic diseases, and differences in gut microbiota between healthy and atopic children have indeed been shown in several cross-sectional epidemiologic studies. ${ }^{1-5}$ In the prospective Child, Parent and Health: Lifestyle and Genetic Constitution (acronym KOALA in Dutch) Birth Cohort Study, we showed in addition that differences in the gut microbiota composition precede the development of childhood atopic manifestations (eczema, recurrent wheeze, and allergic sensitization). ${ }^{6}$

For example, colonization by Escherichia coli, a major gramnegative constituent of the infant microbiota, was shown to be associated with the development of eczema.

Microbes are recognized by the innate immune system using pattern recognition receptors (PRRs). CD14 is, together with Tolllike receptor (TLR)-4, involved in the recognition and signal transduction of bacterial endotoxin, a major component of the bacterial cell wall of gram-negative bacteria. Downstream effects of CD14/TLR receptor activation on antigen presenting cells include the release of cytokines, such as IL-10 and IL-12.

Asthma and allergy are complex diseases - that is, both genetic and environmental factors contribute to disease development. Polymorphisms in the PRR encoding genes might alter immune responsiveness of the host to microbial agents, thereby modifying the development of immune-mediated diseases like asthma and atopy. So far, TLR4 and CD14 gene association studies with asthma and atopy are suggestive for a genetic component, but results have varied between studies. ${ }^{8}$

One of the most likely explanations for discrepancies between studies is differences in the level of microbial exposures interacting with the PRRs. For example, a single nucleotide polymorphism (SNP) in TLR4 (Asp299Gly) was associated with a lower prevalence of bronchial responsiveness and allergy in 2 independent populations, but only in subjects heavily exposed to endotoxin. ${ }^{9,10}$ Several studies have reported that the association between a functional SNP in the promoter region of $C D 14$ $(-159 \mathrm{C}-\mathrm{T})$ and total serum IgE levels is modified by the level of exposure to microbial products/endotoxin. ${ }^{11}$ Furthermore, Bieli et $\mathrm{al}^{12}$ showed that the protective effect of farm milk consumption on allergic diseases is stronger in children carrying the A allele in CD14/-1721 than in children homozygous for the G allele. 


\author{
Abbreviations used \\ AD: Atopic dermatitis \\ ALEX: Allergy and Endotoxin \\ FDR: False discovery rate \\ KOALA: Child, Parent and Health: Lifestyle and Genetic Constitution \\ OR: Odds ratio \\ PRR: Pattern recognition receptor \\ SNP: Single nucleotide polymorphism \\ TLR: Toll-like receptor \\ UK-WP: UK Working Party
}

So far, no gene-environment studies have been performed with respect to the most extensive source of microbial stimulation, the gut microbiota.

The aim of the current study is to examine the interaction between fecal E coli and SNPs in the CDI4 and TLR 4 genes in relation to the development of atopic manifestations.

\section{METHODS}

\section{Subjects and study design}

This study is conducted within the KOALA Birth Cohort Study, a prospective cohort in The Netherlands, described in detail elsewhere. ${ }^{13}$ Briefly, pregnant women were recruited at 34 weeks of gestation. During pregnancy and early childhood, data on perinatal determinants of the child's health as well as on hygiene, infections, nutrition, child-rearing, other lifestyle characteristics, and atopic manifestations were collected for all members of the cohort by repeated questionnaires at 34 weeks of gestation and 3, 7, 12, and 24 months postpartum.

Participants recruited from January 2002 onward were asked to consent to sample the infant's feces at the age of 1 month postpartum $(n=1176)$. After exclusion of premature infants, infants who received antimicrobial agents during their first month of life, infants of whom an insufficient amount of feces $(<1 \mathrm{~g})$ was collected, infants of whom feces was not collected between the age of 3 and 6 weeks postpartum, and infants for whom the feces questionnaire was missing, the study cohort included 957 infants. ${ }^{6}$

The KOALA study was approved by the Ethical Committee of the University Hospital of Maastricht, and all parents signed informed consent for the study.

\section{Fecal microbiota composition}

The collection and processing of fecal samples has been described in detail elsewhere. ${ }^{6}$ Briefly, parents collected a fecal sample by placing a sanitary napkin in the diaper (to prevent absorption of the feces by the diaper) and collected the feces out of the napkin into the collection tube and sent it immediately to our laboratory by post. At the laboratory, fecal samples were 10-fold diluted in peptone-water (Oxoid CM0009, Hampshire, UK) containing 20\% vol/vol glycerol (Merck, Damstadt, Germany) and stored at $-20{ }^{\circ} \mathrm{C}$ until analysis. DNA was extracted by a combination of bead-beating and the QIAamp DNA Stool Mini Kit (Qiagen, Venlo, The Netherlands). Fecal samples were subjected to real-time PCRs for the enumeration of, among others, E coli and total bacterial counts. Samples were considered to be positive for $E$ coli when threshold cycle values were below 35 .

The $\log _{10}$ colony-forming units per gram were calculated for each stool sample from the threshold cycle values by using the constructed standard curves. Subsequently, samples were classified as yielding low or high $E$ coli concentrations by using the median of detectable levels $\left(9.35 \log _{10}\right.$ colonyforming units) as a cut-off.

\section{Measurement of infant's specific IgE}

Venous blood of the infants was collected during a home visit at 2 years postpartum. Infants' venous blood samples were analyzed for specific IgE against hen's eggs, cow's milk, peanuts, birch, grass pollen, cat, dog, and house dust mite by using a RAST as described earlier. ${ }^{14}$ The detection limit for specific IgE was $0.10 \mathrm{IU} / \mathrm{mL}$.

\section{Definition of infant's atopic manifestations and sensitization}

Infants were defined as having developed eczema in the first 2 years of life if their parents reported an itchy rash that was coming and going in the past months based on the 7-month, 12-month, and 24-month postpartum questionnaires, which were based on International Study of Asthma and Allergies in Childhood (ISAAC) questions. Subjects with only diaper rash, rash around the eyes, and/or scalp scaling were not considered to have eczema.

As a stricter eczema phenotype, we defined atopic dermatitis (AD) according to the United Kingdom Working Party (UK-WP) criteria ${ }^{15}$ for all infants who were visited at home at age 2 years and examined by the trained research nurse. The probability of the presence of $\mathrm{AD}$ was derived from the presence of 4 clinical symptoms: (1) presence of itchy rash (coded as $0=$ absent, $1=$ present $),(2)$ history of flexural dermatitis $(0=$ absent, $1=$ present), (3) visible flexural dermatitis $(0=$ absent, $1=$ present $)$, and (4) onset before age 2 years $(0=$ absent, $1=$ present $)$. The UK-WP probability score of $\mathrm{AD}$ is then computed as follows:

$$
\text { probability } \mathrm{AD}=\text { odds }(\mathrm{AD}) /[\text { odds }(\mathrm{AD})+1]
$$

where odds $(\mathrm{AD})=\exp [-4.36+1.84$ (history of flexural dermatitis $)+3.46$ (onset before age 2 years) +2.09 (visible flexural dermatitis) +1.71 (presence of itchy rash)]. ${ }^{15}$ In this study, infants with a UK-WP probability score of AD $>90 \%$ were regarded as infants with AD.

Infants were classified as having allergic sensitization when serum $\operatorname{IgE}$ levels were $>0.3 \mathrm{IU} / \mathrm{mL}$ against 1 or more of the tested food or inhalant allergens.

\section{DNA collection, processing, and genotyping}

Parents were asked to collect buccal swabs as a source of DNA from their children.

Genomic DNA was extracted from these swabs from using standard methods. ${ }^{16}$ DNA was amplified by using REPLI-g UltraFast technology (Qiagen). Genotyping was performed by Competitive Allele-Specific PCR using KASPar genotyping chemistry, under contract by K-Biosciences with extensive quality control as described previously. ${ }^{17}$

\section{SNP selection}

Haplotype tagging SNPs were selected from publicly available databases of the International HapMap Project, version $2005,{ }^{18}$ and from the Innate Immunity web site ${ }^{19}$ depending on the largest number of SNPs with a minor allele frequency $>0.1$ available in each database. In addition, the biomedical literature was screened for SNPs with known functional impact or association with asthma or atopy.

\section{Statistical analysis}

Genotype distribution was tested for deviations $(P<.05)$ from HardyWeinberg equilibrium using $\chi^{2}$ analyses.

We used $\chi^{2}$ tests to analyze whether TLR4 and CD14 SNPs were associated with parentally reported eczema, $\mathrm{AD}$, and allergic sensitization (allergen specific $\mathrm{IgE}>0.3 \mathrm{IU} / \mathrm{mL}$ ) by using a codominant model. For SNPs with $P<.10$, the Akaike information criterion was evaluated to determine the best fitting genetic model (additive, dominant, or recessive).

Subsequently the prevalence of these atopic outcomes was calculated according to $E$ coli colonization. $\chi^{2}$ Tests were used to test for differences in the prevalence of the atopic outcomes according to $E$ coli colonization.

Unadjusted and adjusted odds ratios (ORs) and 95\% CIs for the association between $E$ coli colonization and atopic outcomes according to the different genotypes were calculated by means of logistic regression. The adjusted 
regression models included the following potential confounders: parental atopic history, defined as self-reported doctor's diagnosed eczema, hay fever, asthma, pet and/or house dust mite allergy (both parents nonatopic, at least 1 parent atopic); siblings' atopic history, defined as parentally reported doctor's diagnosed food allergy, eczema, hay fever, asthma, pet and/or house dust mite allergy (no siblings; $\geq 1$ siblings, all none-atopic; or $>1$ siblings, at least 1 atopic); age at collection of fecal sample (age in days), infant's sex (boy, girl); pet exposure at home (no pet exposure; only cat exposure; only dog exposure; only other furry pet exposure; combination of cat, dog, and/or other furry pet exposure); and recruitment group (alternative, conventional). ${ }^{13}$

Multiple logistic regression was used for analyses, and thus, departure from a multiplicative model of interaction on the OR scale was investigated. The statistical significance of effect modification was tested by a likelihood ratio test for the improvement of goodness of model fit when including the interaction term of genotype and $E$ coli colonization into the logistic regression models. Thus, the obtained $P$ value for interaction estimates a departure from a multiplicative interaction model on the OR scale and indicates whether the effect (OR) of E coli colonization is altered by effects of CD14 or TLR4 genotype.

All analyses were performed by using SPSS 15.0 statistical software, and results were considered statistically significant when the $P$ value was lower than .05. To control for multiple testing, we calculated the false discovery rate (FDR) for the tests for interaction according to Benjamini and Hochberg. ${ }^{20}$

\section{RESULTS}

\section{Study population and genetic analysis}

DNA from buccal swabs was available for genetic analyses in 681 of the 957 children $(71.2 \%)$ from whom fecal samples had been collected at age 1 month. As shown in Table I, characteristics were comparable between subjects with and without genetic data. Furthermore, as shown previously, ${ }^{6}$ infants who provided a fecal sample did not differ from those who did not provide a fecal sample.

Of the 9 genotyped TLR4 SNPs, the rs10759931 SNP deviated from Hardy-Weinberg equilibrium and was not considered for further analysis. None of the 5 genotyped $C D 14$ SNPs deviated from Hardy-Weinberg equilibrium (Table II). Fig 1, A, shows the position of the genotyped SNPs within the TLR4 and CD14 genes. Fig $1, B$, shows the linkage disequilibrium between these SNPs as presented by D' and $r^{2}$. D' is presented as a number if it deviates from 100. D' is 100 when no recombination has occurred between 2 SNPs. $r^{2}$ is represented by color, changing from dark gray when $r^{2}=1$ (the minor alleles at 2 SNP positions are always present on the same haplotype) to white when $r^{2}=0$ (the minor alleles are always on separate haplotypes).

\section{Genetic association of TLR4 and CD14 and atopy}

This article's Table E1 in the Online Repository at www. jacionline.org shows the prevalence of atopic outcomes according to the TLR4 and CDI4 genotypes. One TLR4 SNP(rs2770150) was borderline significantly associated with $\mathrm{AD}$ according to the UKWP criteria. Furthermore, a borderline significant association were found between parentally reported eczema and 3 CDI4 SNPs (rs2569190, rs2569191, rs2915863), with the prevalence of eczema always lowest in the minor allele homozygotes.

None of the TLR4 and CDI4 SNPs was associated with allergic sensitization.

\section{Gene-by-environment interaction}

When considering the prevalence of the atopic outcomes according to intestinal $E$ coli colonization at age 1 month
TABLE I. Characteristics of the study population $(n=957)^{*}$

\begin{tabular}{|c|c|c|}
\hline & $\begin{array}{c}\text { Genetic data } \\
(\mathrm{n}=681)\end{array}$ & $\begin{array}{c}\text { No genetic data } \\
(\mathrm{n}=\mathbf{2 7 6}) \\
\end{array}$ \\
\hline $\begin{array}{l}\text { Age at collection of feces } \\
\text { (d), mean (SD) }\end{array}$ & $31.5(3.23)$ & $32.1(3.39)$ \\
\hline \multicolumn{3}{|l|}{$\begin{array}{l}\text { Parental history of atopic } \\
\text { manifestations, n/N (\%) }\end{array}$} \\
\hline $\begin{array}{l}\text { At least } 1 \text { parent with } \\
\text { atopy }\end{array}$ & $373 / 681(54.8)$ & $142 / 276(51.4)$ \\
\hline \multicolumn{3}{|l|}{$\begin{array}{l}\text { Sibling history of atopic } \\
\text { manifestations, } \mathrm{n} / \mathrm{N}(\%)\end{array}$} \\
\hline No siblings & $269 / 681(39.5)$ & $116 / 276(42.0)$ \\
\hline $\begin{array}{l}\geq 1 \text { siblings, all } \\
\text { nonatopic }\end{array}$ & $294 / 681(43.2)$ & $111 / 276(40.2)$ \\
\hline $\begin{array}{l}\geq 1 \text { siblings, at least } \\
1 \text { atopic }\end{array}$ & $118 / 681(17.3)$ & 48/276 (17.4) \\
\hline Sex of infant, boys, $\mathrm{n} / \mathrm{N}(\%)$ & $351 / 681(51.5)$ & $134 / 276(48.6)$ \\
\hline \multicolumn{3}{|l|}{ Pets at home, $\mathrm{n} / \mathrm{N}(\%)$} \\
\hline No pets & $365 / 681(53.6)$ & $145 / 276(52.5)$ \\
\hline Cat & 97/681 (14.4) & $57 / 276(20.7)$ \\
\hline Dog & $151 / 681(22.2)$ & $49 / 276(17.8)$ \\
\hline Other furry pet & $22 / 681(3.2)$ & $9 / 276(3.2)$ \\
\hline $\begin{array}{l}\text { Combination of cat, dog, } \\
\text { and/or other furry pet }\end{array}$ & 45/681 (6.6) & $16 / 276(5.8)$ \\
\hline \multicolumn{3}{|l|}{$\begin{array}{l}\text { Infants atopic outcome at } \\
\text { age } 2 \mathrm{y}, \mathrm{n} / \mathrm{N}(\%)\end{array}$} \\
\hline Eczema & $219 / 678(32.3)$ & $85 / 259(32.8)$ \\
\hline $\begin{array}{l}\text { Atopic dermatitis } \\
(\text { UK-WP }) \dagger\end{array}$ & $82 / 513(16.0)$ & 16/94 (17.0) \\
\hline Sensitization $\dagger$ & $140 / 499(28.1)$ & 25/84 (29.8) \\
\hline
\end{tabular}

*Overall numbers are not always 957 because of missing data.

†Only available for those infants visited at home $(n=607)$.

postpartum, infants colonized with this bacterium were at increased risk of developing eczema in the subsequent 2 years (see this article's Table E2 in the Online Repository at www. jacionline.org). This increased risk was highest for infants with high fecal $E$ coli concentrations (as described previously in the complete cohort). ${ }^{6}$

This article's Tables E3 to E5 in the Online Repository at www.jacionline.org show the associations between $E$ coli colonization at age 1 month postpartum and parentally reported eczema, clinically diagnosed $\mathrm{AD}$ (UK-WP criteria), and allergic sensitization, respectively, stratified for the TLR4 and CD14 SNPs. Almost none of the SNPs showed significant multiplicative interaction with $E$ coli exposure for either eczema (parental report or UK-WP criteria) or allergic sensitization.

A statistically significant multiplicative interaction was found for the TLR4 SNP rs10759932 ( $P$ for interaction $=.001)$ and $E$ coli exposure in association with allergic sensitization. After controlling for multiple testing by FDR, the interaction remained statistically significant.

E coli colonization was associated with a strongly decreased risk of sensitization in children homozygous for the T allele $(\mathrm{n}=357$; adjusted OR, 0.31; 95\% CI: 0.14-0.68). By contrast, heterozygotic children were at increased risk of sensitization, although not statistically significantly, when colonized by $E$ coli $(\mathrm{n}=108$; adjusted OR, 6.68; 95\% CI: 0.75-64.96; note: for C homozygotes, the OR was not calculated because the number of subjects was only 5). In addition, a secondary analysis was performed to examine the risk of allergic sensitization according to the concentration of fecal E coli stratified for the TLR4 rs10759932 genotype. T homozygotes 
TABLE II. Selected TLR4 and CD14 SNPs and minor allele frequencies in the study population

\begin{tabular}{|c|c|c|c|c|c|}
\hline Gene & Rs number & Alleles* & Synonym & Minor allele frequency & $\begin{array}{c}P \text { value } \dagger \text { for Hardy- } \\
\text { Weinberg equilibrium }\end{array}$ \\
\hline$T L R 4$ & rs2770150 & $\mathrm{T}>\mathrm{C}$ & c. $-3612 \mathrm{~T} / \mathrm{C}$ & 0.26 & .97 \\
\hline TLR4 & rs10759931 & $\mathrm{G}>\mathrm{A}$ & c. $-2604 \mathrm{G} / \mathrm{A}$ & 0.43 & $<.001$ \\
\hline TLR4 & rs6478317 & $A>G$ & c. $-2570 \mathrm{~A} / \mathrm{G}$ & 0.35 & .19 \\
\hline TLR4 & rs 10759932 & $\mathrm{~T}>\mathrm{C}$ & c. $-1607 \mathrm{~T} / \mathrm{C}$ & 0.13 & .86 \\
\hline TLR4 & rs 1927911 & $\mathrm{C}>\mathrm{T}$ & c. $93+3211 \mathrm{C} / \mathrm{T}$ & 0.26 & .68 \\
\hline TLR4 & rs11536878 & $\mathrm{C}>\mathrm{A}$ & c. $260+546 \mathrm{C} / \mathrm{A}$ & 0.12 & .43 \\
\hline TLR4 & rs4986790 & $\mathrm{A}>\mathrm{G}$ & Asp299Gly & 0.07 & .84 \\
\hline TLR4 & rs4986791 & $\mathrm{C}>\mathrm{T}$ & Thr399Ile & 0.08 & $>.999$ \\
\hline TLR4 & rs11536889 & $\mathrm{G}>\mathrm{C}$ & c. $3648+78 \mathrm{G} / \mathrm{C}$ & 0.15 & .83 \\
\hline CD14 & rs2915863 & $\mathrm{T}>\mathrm{C}$ & $-1619 \mathrm{~T} / \mathrm{C}$ & 0.41 & .70 \\
\hline$C D 14$ & rs2569191 & $\mathrm{T}>\mathrm{C}$ & $-1145 \mathrm{~T} / \mathrm{C}$ & 0.48 & $>.999$ \\
\hline CD14 & rs 5744455 & $\mathrm{C}>\mathrm{T}$ & $-550 \mathrm{C} / \mathrm{T}$ & 0.23 & .20 \\
\hline$C D 14$ & rs2569190 & $\mathrm{C}>\mathrm{T}$ & $-159 \mathrm{C} / \mathrm{T}$ & 0.48 & .71 \\
\hline CD14 & rs 2563298 & $\mathrm{C}>\mathrm{A}$ & 3'UTR & 0.26 & .52 \\
\hline
\end{tabular}

*Minor alleles first.

$\dagger$ As determined by $\chi^{2}$ test.

A TLR4

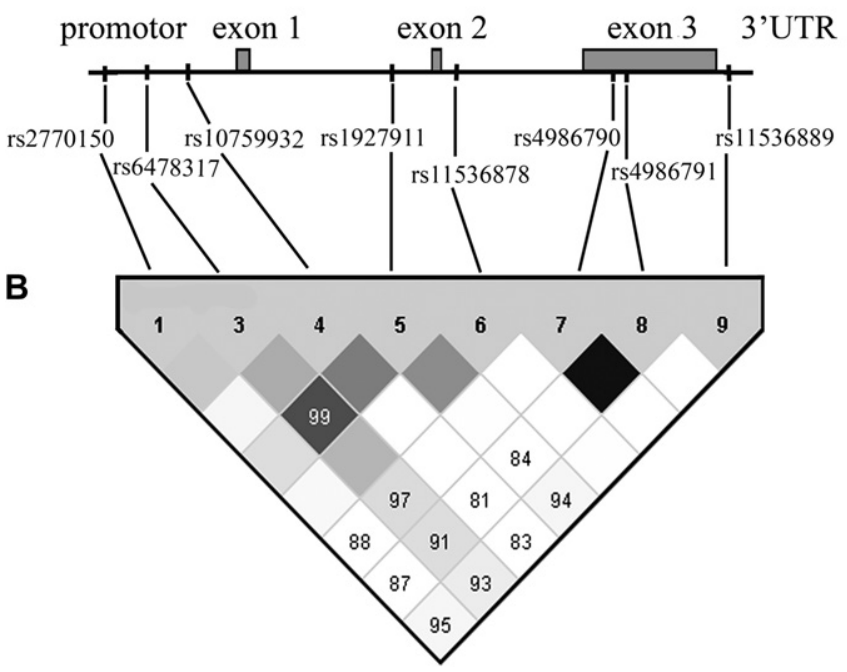

CD14

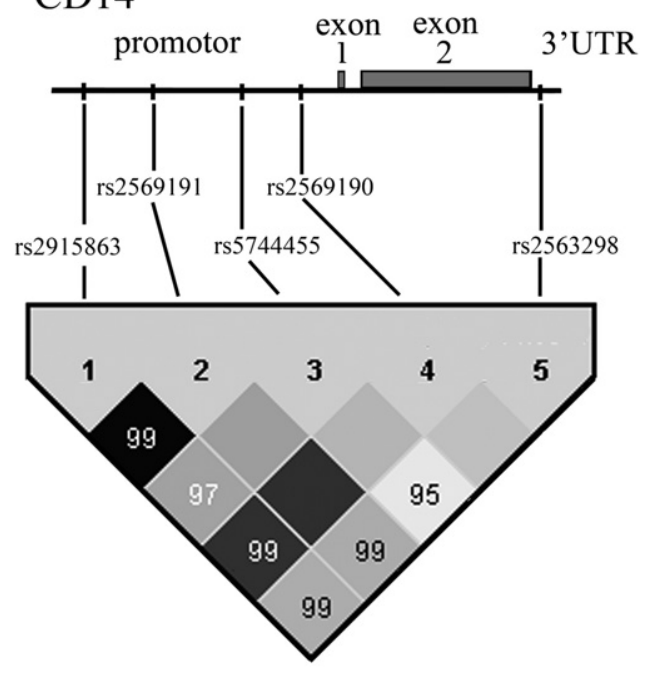

FIG 1. Position and linkage disequilibrium of the SNPs within TLR4 and CD14. A, TLR4 is located on chromosome 9 (9q32) 119,506,431. CD14 is located on chromosome 5 (5q31) 139991505. B, Pairwise linkage disequilibrium plot according to Haploview3.32 ${ }^{29}$ for $T L R 4$ and $C D 14$ SNPs. D' is presented as a number if it deviates from 100. The measure of $r^{2}$ is represented by color, changing from dark gray when $r^{2}=1$ to white when $r^{2}=0$. UTR, Untranslated region.

colonized with low and high concentrations had a comparable decreased risk for developing allergic sensitization as compared with uncolonized children (adjusted OR [95\% CI], respectively, 0.29 [0.13-0.67] and 0.33 [0.15-0.76]). Heterozygotes colonized with low or high concentrations were at a similar risk for developing allergic sensitization (adjusted OR [95\% CI], respectively, 6.6 [0.6963.5] and 7.8 [0.76-80.7]). $P$ for interaction was .005 .

Fig 2 shows that the effect of this SNP was in the same direction when analyzing eczema (both parentally reported and clinically diagnosed $\mathrm{AD}$ according to UK-WP criteria).

Furthermore, a borderline significant multiplicative interaction was found between $E$ coli and the rs2569190 (CD14/-159) SNP regarding allergic sensitization (Table E5). E coli colonization was associated with an increased risk of sensitization in CC homozygotes, whereas it was associated with a decreased risk of sensitization in heterozygotes and even more in TT homozygotes. However, this interaction did not withstand correction for multiple testing by FDR.

\section{DISCUSSION}

Within the KOALA Birth Cohort Study, we have examined the interaction between intestinal $E$ coli colonization at 1 month of age and TLR4/CD14 haplotype tagging and functional SNPs in association with subsequent development of eczema and allergic sensitization. To our knowledge, this is the first prospective study investigating the interaction between intestinal microbes and candidate genes in association with allergy development.

When considering the host and microbial factors separately, none of the TLR4 SNPs, nor E coli colonization, were associated with 


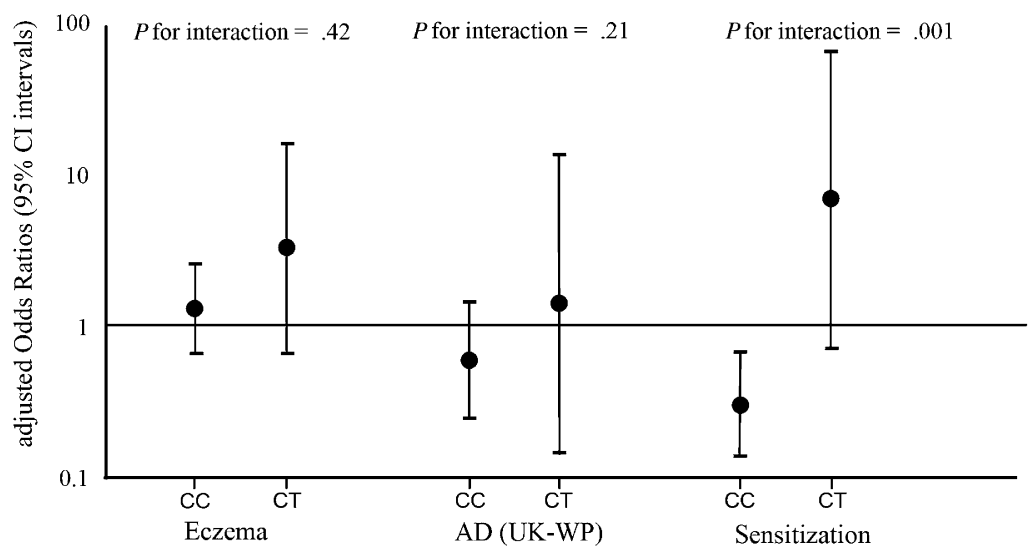

FIG 2. Association between $E$ coli and atopic outcomes stratified for TLR4 SNP rs10759932. The figure shows the adjusted ORs for the development of eczema, $A D$, and sensitization in infants colonized with $E$ coli compared with uncolonized infants (reference category, $\mathrm{OR}=1$ ) stratified according to genotype.

allergic sensitization. However, CC homozygotes for the TLR4 rs1927911 SNP had a significantly decreased risk to become sensitized if they were colonized with $E$ coli in early infancy.

Furthermore, a significant multiplicative interaction was found for $E$ coli colonization and the TLR4 SNP rs 10759932 with respect to allergic sensitization. E coli colonization was associated with a strongly decreased risk of sensitization among $\mathrm{T}$ homozygotes, whereas it was associated with an increased risk of sensitization among heterozygotic children (cross-over interaction).

This association between $E$ coli and allergic sensitization would never have been detected if the genotype had not been taken into account, because the positive association in the heterozygotes and the negative association in the homozygotes evens out to no association when both groups are combined. This demonstrates the importance of gene-environment interactions, with effects of genes and/or microbial factors masked when they are not being studied together.

To our knowledge, these SNPs (rs10759932 and rs1927911) have not been linked to atopic sensitization or symptoms previously but have been linked to several other diseases like prostate cancer, chorionic plate inflammation, and myocardial infarction. ${ }^{21-24}$

Because of the strong regional correlation between SNPs across TLR4, rs10759932 may serve as a proxy for the predisposing variant, or the polymorphism itself may have functional consequences on TLR4 activity. $^{22}$

Among the most extensively studied TLR4 SNPs in association with allergic diseases are Asp299Gly and Thr399Ile (respectively, rs4986790 and rs4986791), 2 common cosegregating missense mutations. Arbour et $\mathrm{al}^{25}$ reported that these SNPs are associated with airway hyporesponsiveness and that the TLR4 Asp299Gly variant interrupted TLR4-mediated LPS-signaling.

Within the Allergy and Endotoxin (ALEX) study, genetic variation in TLR4 Asp299Gly (rs4986790) was found to be associated with increased risk of sensitization to aeroallergens in children heavily exposed to endotoxin. ${ }^{9}$ This indicates that TLR4 SNP may be mainly associated with sensitization with inhalation allergens and respiratory allergies. Because the natural development of sensitization starts with sensitization to food allergens in infancy, which decreases over time, whereas specific IgE to indoor allergens increases in later childhood, ${ }^{26}$ associations may be found only in later childhood. This might explain the lack of association with this particular TLR4 SNP in the current study.
We found no significant departure from multiplicativity regarding $C D 14$ polymorphisms and $E$ coli colonization, except for a borderline significant interaction between $C D 14-159 \mathrm{C} / \mathrm{T}$ and $E$ coli in association with allergic sensitization. Both the ALEX study $^{27}$ and the Manchester Asthma and Allergy Study (MAAS) ${ }^{11}$ found support for the endotoxin switch theory as proposed by Vercelli, ${ }^{28}$ where the C allele of this CD14/-159 SNP confers risk at low endotoxin exposures whereas the $\mathrm{T}$ allele confers risk at high exposures of endotoxin. Our data do not support a protective effect of high endotoxin exposure on sensitization in $\mathrm{C}$ homozygotes.

One possible explanation is that the influences of CD14-environment interactions on atopy are age-specific, as recently demonstrated by Bottema et al. ${ }^{17}$ In that study, partly based on the same population as the current study, interactions between CD14 polymorphisms and pet exposure influenced total and specific IgE levels at 4 and 8 years, but not at 1 and 2 years. Therefore, the influence of $C D 14$-environment interactions may be stronger in midchildhood compared with infancy. This is in agreement with the fact that both the ALEX and the Manchester Asthma and Allergy Study determined allergic sensitization in midchildhood (5-13 years), whereas specific IgE was determined at age 2 years in the current study.

An accurate definition of the disease outcome in genetic studies is important, because misclassification of individuals reduces the power of genetic studies to a great extent. This might be an explanation for the fact that significant interactions were limited to allergic sensitization, a more objective disease outcome than eczema and therefore less prone to misclassification.

To minimize the chance that $E$ coli colonization is merely an epiphenomenon of an underlying immunologic disease, we have determined colonization very early in life when allergic diseases had not manifested yet. Furthermore, statistical analyses were adjusted for family history of atopy to control for the possibility that a familial predisposition to allergies is associated with a predisposition to become colonized with $E$ coli.

Although this is the largest cohort study to date in which fecal samples have been analyzed, the high proportion of $E$ coli colonization, and thus the low proportion of unexposed infants, negatively influences the power of the current study. Nevertheless, we did find a multiplicative interaction between $E$ coli and TLR4 rs10759932 in association with allergic sensitization that 
persisted after controlling for FDR. These findings support the hypothesis that the association between the intestinal microbiota and allergic diseases is mediated by genetic variations in pattern recognition receptors.

Further research on the immune-modulating effect of intestinal microbes and the modifying role of host genetics may lead us to attractive new routes to modulate the gut microbiota to treat or prevent allergic diseases in susceptible individuals.

We thank the children and parents of the KOALA study for their participation. In addition, we thank the KOALA field team for their efforts in sample collection.

Clinical implications: Our results support the hypothesis that the association between fecal $E$ coli and allergic sensitization is mediated by genetic variations in TLR4.

\section{REFERENCES}

1. Bjorksten B, Naaber P, Sepp E, Mikelsaar M. The intestinal microflora in allergic Estonian and Swedish 2-year-old children. Clin Exp Allergy 1999;29:342-6.

2. Bjorksten B, Sepp E, Julge K, Voor T, Mikelsaar M. Allergy development and the intestinal microflora during the first year of life. J Allergy Clin Immunol 2001;108:516-20.

3. Kalliomaki M, Kirjavainen P, Eerola E, Kero P, Salminen S, Isolauri E. Distinct patterns of neonatal gut microflora in infants in whom atopy was and was not developing. J Allergy Clin Immunol 2001;107:129-34.

4. Sepp E, Julge K, Mikelsaar M, Bjorksten B. Intestinal microbiota and immunoglobulin E responses in 5-year-old Estonian children. Clin Exp Allergy 2005;35:1141-6.

5. Watanabe S, Narisawa Y, Arase S, Okamatsu H, Ikenaga T, Tajiri Y, et al. Differences in fecal microflora between patients with atopic dermatitis and healthy control subjects. J Allergy Clin Immunol 2003;111:587-91.

6. Penders J, Thijs C, van den Brandt PA, Kummeling I, Snijders B, Stelma F, et al. Gut microbiota composition and development of atopic manifestations in infancy: the KOALA birth cohort study. Gut 2007;56:661-7.

7. Vercelli D. Innate immunity: sensing the environment and regulating the regulators. Curr Opin Allergy Clin Immunol 2003;3:343-6.

8. Koppelman GH. Gene by environment interaction in asthma. Curr Allergy Asthma Rep 2006;6:103-11.

9. Eder W, Klimecki W, Yu L, von Mutius E, Riedler J, Braun-Fahrlander C, et al Toll-like receptor 2 as a major gene for asthma in children of European farmers. J Allergy Clin Immunol 2004;113:482-8.

10. Werner M, Topp R, Wimmer K, Richter K, Bischof W, Wjst M, et al. TLR4 gene variants modify endotoxin effects on asthma. J Allergy Clin Immunol 2003;112: 323-30.

11. Simpson A, John SL, Jury F, Niven R, Woodcock A, Ollier WE, et al. Endotoxin exposure, CD14, and allergic disease: an interaction between genes and the environment. Am J Respir Crit Care Med 2006;174:386-92.
12. Bieli C, Eder W, Frei R, Braun-Fahrlander C, Klimecki W, Waser M, et al. A polymorphism in CD14 modifies the effect of farm milk consumption on allergic diseases and CD14 gene expression. J Allergy Clin Immunol 2007;120:1308-15.

13. Kummeling I, Thijs C, Penders J, Snijders BEP, Stelma F, Reimerink J, et al. Etiology of atopy in infancy: the KOALA Birth Cohort Study. Pediatr Allergy Immunol 2005;16:679-84.

14. Aalberse RC, Koshte V, Clemens JG. Immunoglobulin E antibodies that crossreact with vegetable foods, pollen, and Hymenoptera venom. J Allergy Clin Immunol 1981;68:356-64

15. Williams HC, Burney PG, Hay RJ, Archer CB, Shipley MJ, Hunter JJ, et al. The U.K. Working Party's diagnostic criteria for atopic dermatitis, I: derivation of a minimum set of discriminators for atopic dermatitis. Br J Dermatol 1994;131: 383-96.

16. Sambrook J, Russell D. Molecular cloning, a laboratory manual, 3rd ed. New York: Cold Spring Harbor Laboratory Press; 2001.

17. Bottema RW, Reijmerink NE, Kerkhof M, Koppelman GH, Stelma FF, Gerritsen J, et al. IL13, CD14, pet and tobacco smoke influence atopy in 3 Dutch cohorts; the Allergenic Study. Eur Respir J 2008;32:593-602.

18. International HapMap Consortium. A haplotype map of the human genome. Nature 2005;437:1299-320.

19. Lazarus R, Vercelli D, Palmer LJ, Klimecki WJ, Silverman EK, Richter B, et al. Single nucleotide polymorphisms in innate immunity genes: abundant variation and potential role in complex human disease. Immunol Rev 2002;190:9-25.

20. Benjamini Y, Hochberg Y. Controlling the false discovery rate: a practical and powerful approach to multiple testing. J R Stat Soc B 1995;57:289-300.

21. Chen YC, Giovannucci E, Lazarus R, Kraft P, Ketkar S, Hunter DJ. Sequence variants of Toll-like receptor 4 and susceptibility to prostate cancer. Cancer Res 2005; 65:11771-8

22. Cheng I, Plummer SJ, Casey G, Witte JS. Toll-like receptor 4 genetic variation and advanced prostate cancer risk. Cancer Epidemiol Biomarkers Prev 2007;16: 352-5.

23. Enquobahrie DA, Smith NL, Bis JC, Carty CL, Rice KM, Lumley T, et al. Cholesterol ester transfer protein, interleukin-8, peroxisome proliferator activator receptor alpha, and Toll-like receptor 4 genetic variations and risk of incident nonfatal myocardial infarction and ischemic stroke. Am J Cardiol 2008;101:1683-8.

24. Simhan HN, MacPherson T, Caritis SN, Krohn MA. Maternal and fetal Toll-like receptor 4 genotype and chorionic plate inflammatory lesions. Am J Obstet Gynecol 2008;199:400:e1-4

25. Arbour NC, Lorenz E, Schutte BC, Zabner J, Kline JN, Jones M, et al. TLR4 mutations are associated with endotoxin hyporesponsiveness in humans. Nat Genet 2000;25:187-91.

26. Kulig M, Bergmann R, Klettke U, Wahn V, Tacke U, Wahn U. Natural course of sensitization to food and inhalant allergens during the first 6 years of life. J Allergy Clin Immunol 1999;103:1173-9.

27. Eder W, Klimecki W, Yu L, von Mutius E, Riedler J, Braun-Fahrlander C, et al. Opposite effects of CD 14/-260 on serum IgE levels in children raised in different environments. J Allergy Clin Immunol 2005;116:601-7.

28. Vercelli D. Learning from discrepancies: CD14 polymorphisms, atopy and the endotoxin switch. Clin Exp Allergy 2003;33:153-5.

29. Barrett JC, Fry B, Maller J, Daly MJ. Haploview: analysis and visualization of LD and haplotype maps. Bioinformatics 2005;21:263-5. 
TABLE E1. Prevalence (\%) of atopic outcomes according to CD14 and TLR4 genotype

\begin{tabular}{|c|c|c|c|c|}
\hline & & $\begin{array}{l}\text { Eczema Percent } \\
\text { (cases/total) }\end{array}$ & $\begin{array}{l}\text { AD* Percent } \\
\text { (cases/total) }\end{array}$ & $\begin{array}{l}\text { Sensitization Percen } \\
\text { (cases/total) }\end{array}$ \\
\hline $\begin{array}{l}T L R 4 \text { c. }-3612 \\
(\mathrm{rs} 2770150)\end{array}$ & $\begin{array}{l}\text { TT } \\
\text { CT } \\
\text { CC }\end{array}$ & $\begin{array}{c}34.7(127 / 366) \\
28.9(74 / 256) \\
34.9(15 / 43) \\
P=.30\end{array}$ & $\begin{array}{c}19.1(52 / 272) \\
11.9(24 / 202) \\
12.9(4 / 31) \\
\quad P=.09\end{array}$ & $\begin{array}{l}28.1(74 / 263) \\
26.9(53 / 197) \\
32.3(10 / 31) \\
P=.82\end{array}$ \\
\hline $\begin{array}{l}T L R 4 \text { c. }-2570 \\
\text { (rs6478317) }\end{array}$ & $\begin{array}{l}\text { AA } \\
\text { GA } \\
\text { GG }\end{array}$ & $\begin{array}{c}32.2(87 / 270) \\
32.8(105 / 320) \\
29.3(22 / 75) \\
P=.85\end{array}$ & $\begin{array}{c}16.1(33 / 205) \\
16.5(40 / 242) \\
10.5(6 / 57) \\
\quad P=.52\end{array}$ & $\begin{array}{l}29.5(59 / 200) \\
26.0(61 / 235) \\
32.7(18 / 55) \\
P=.52\end{array}$ \\
\hline $\begin{array}{l}\text { TLR4 c. }-1607 \\
\text { (rs10759932) }\end{array}$ & $\begin{array}{l}\mathrm{TT} \\
\mathrm{CT} \\
\mathrm{CC} \dagger\end{array}$ & $\begin{array}{c}32.2(155 / 481) \\
32.0(47 / 147) \\
40.0(4 / 10) \\
\quad P=.87\end{array}$ & $\begin{array}{l}16.6(61 / 368) \\
14.4(16 / 111) \\
20.0(1 / 5) \\
\quad P=.59\end{array}$ & $\begin{array}{l}28.4(102 / 359) \\
29.6(32 / 108) \\
20.0(1 / 5) \\
P=.81\end{array}$ \\
\hline $\begin{array}{l}\text { TLR4 c.93 + } 3211 \\
(\mathrm{rs} 1927911)\end{array}$ & $\begin{array}{l}\mathrm{CC} \\
\mathrm{CT} \\
\mathrm{TT}\end{array}$ & $\begin{array}{c}33.4(119 / 356) \\
30.2(78 / 258) \\
35.7(15 / 42) \\
P=.63\end{array}$ & $\begin{array}{c}17.0(46 / 270) \\
13.5(27 / 200) \\
17.2(5 / 29) \\
P=.56\end{array}$ & $\begin{array}{l}30.3(79 / 261) \\
25.0(49 / 196) \\
34.5(10 / 29) \\
P=.35\end{array}$ \\
\hline $\begin{array}{l}\text { TLR4 Asp299Gly } \\
\text { (rs4986790) }\end{array}$ & $\begin{array}{l}\mathrm{AA} \\
\mathrm{GA} \\
\mathrm{GG}^{\dagger}\end{array}$ & $\begin{array}{l}32.6(187 / 573) \\
30.2(26 / 86) \\
50.0(2 / 4) \\
\quad P=.66\end{array}$ & $\begin{array}{c}16.3(71 / 435) \\
15.4(10 / 65) \\
0(0 / 3) \\
P=.84\end{array}$ & $\begin{array}{c}28.4(121 / 426) \\
29.5(18 / 61) \\
0(0 / 2) \\
P=.86\end{array}$ \\
\hline $\begin{array}{l}\text { TLR4 Thr399lle } \\
\text { (rs4986791) }\end{array}$ & $\begin{array}{l}\mathrm{CC} \\
\mathrm{CT} \\
\mathrm{TT}^{\dagger}\end{array}$ & $\begin{array}{l}32.7(183 / 560) \\
30.0(27 / 90) \\
50.0(2 / 4) \\
\quad P=.61\end{array}$ & $\begin{array}{c}16.0(68 / 425) \\
13.8(9 / 65) \\
0(0 / 3) \\
P=.66\end{array}$ & $\begin{array}{l}28.8(120 / 416) \\
27.9(17 / 61) \\
0(0 / 2) \\
P=.87\end{array}$ \\
\hline $\begin{array}{l}\text { TLR4 c. } 3648+78 \\
\text { (rs11536889) }\end{array}$ & $\begin{array}{l}\mathrm{GG} \\
\mathrm{CG} \\
\mathrm{CC}^{\dagger}\end{array}$ & $\begin{array}{l}33.2(159 / 479) \\
28.4(48 / 169) \\
38.5(5 / 13) \\
\quad P=.25\end{array}$ & $\begin{array}{c}16.6(60 / 362) \\
14.1(18 / 128) \\
27.3(3 / 11) \\
\quad P=.50\end{array}$ & $\begin{array}{l}30.0(105 / 350) \\
22.2(28 / 126) \\
27.3(3 / 11) \\
P=.10\end{array}$ \\
\hline $\begin{array}{l}C D 14 /-1145 \\
\text { (rs2569191) }\end{array}$ & $\begin{array}{l}\text { TT } \\
\text { CT } \\
\text { CC }\end{array}$ & $\begin{array}{c}30.4(55 / 181) \\
36.0(117 / 325) \\
25.8(40 / 155) \\
\quad P=.07\end{array}$ & $\begin{array}{c}15.0(21 / 140) \\
18.4(44 / 239) \\
10.7(13 / 122) \\
P=.15\end{array}$ & $\begin{array}{l}28.5(39 / 137) \\
28.6(66 / 231) \\
26.9(32 / 119) \\
P=.94\end{array}$ \\
\hline $\begin{array}{l}C D 14 /-550 \\
\text { (rs5744455) }\end{array}$ & $\begin{array}{l}\mathrm{CC} \\
\mathrm{CT} \\
\mathrm{TT}\end{array}$ & $\begin{array}{c}31.0(116 / 374) \\
35.8(86 / 240) \\
25.0(8 / 32) \\
\quad P=.30\end{array}$ & $\begin{array}{c}13.9(40 / 287) \\
20.8(36 / 173) \\
10.3(3 / 29) \\
\quad P=.10\end{array}$ & $\begin{array}{l}27.4(77 / 281) \\
29.8(50 / 168) \\
30.8(8 / 26) \\
P=.83\end{array}$ \\
\hline $\begin{array}{l}C D 14 /-159 \\
(\mathrm{rs} 2569190)\end{array}$ & $\begin{array}{l}\mathrm{CC} \\
\mathrm{CT} \\
\mathrm{TT}\end{array}$ & $\begin{array}{c}30.3(54 / 178) \\
36.5(120 / 329) \\
25.7(39 / 152) \\
\quad P=.05\end{array}$ & $\begin{array}{c}13.9(19 / 137) \\
18.9(46 / 243) \\
10.8(13 / 120) \\
P=.11\end{array}$ & $\begin{array}{l}26.9(36 / 134) \\
29.8(70 / 235) \\
26.5(31 / 117) \\
P=.75\end{array}$ \\
\hline $\begin{array}{l}\text { CD14 3'ÚTR } \\
\text { (rs2563298) }\end{array}$ & $\begin{array}{l}\mathrm{CC} \\
\mathrm{CA} \\
\mathrm{AA}\end{array}$ & $\begin{array}{c}32.3(119 / 368) \\
31.4(76 / 242) \\
36.5(19 / 52) \\
P=.77\end{array}$ & $\begin{array}{c}15.9(44 / 277) \\
15.9(30 / 189) \\
17.1(6 / 35) \\
P=.98\end{array}$ & $\begin{array}{l}29.7(79 / 266) \\
25.8(48 / 186) \\
31.4(11 / 35) \\
P=.61\end{array}$ \\
\hline
\end{tabular}

*AD according to UK-WP criteria

$\dagger$ Minor allele homozygotes excluded from $\chi^{2}$ test analyses because of limited number of subjects.

Boldface indicates statistically significant associations (alpha $=.1$ ) 
TABLE E2. Prevalence (\%) of atopic outcomes according to $E$ colonization

\begin{tabular}{|c|c|c|c|c|}
\hline & & $\begin{array}{c}\text { Eczema } \\
\text { Percent (cases/total) }\end{array}$ & $\begin{array}{c}A D^{*} \\
\text { Percent (cases/total) }\end{array}$ & $\begin{array}{c}\text { Sensitization } \\
\text { Percent (cases/total) }\end{array}$ \\
\hline E coli & $\begin{array}{l}\text { No } \\
\text { Yes }\end{array}$ & $\begin{array}{c}22.2(24 / 108) \\
33.8(279 / 826) \\
\boldsymbol{P}=\mathbf{. 0 1}\end{array}$ & $\begin{array}{c}15.9(10 / 63) \\
16.2(88 / 542) \\
P=.94\end{array}$ & $\begin{array}{c}30.6(19 / 62) \\
28.1(146 / 519) \\
P=.68\end{array}$ \\
\hline E coli & $\begin{array}{l}\text { No } \\
\text { Low } \dagger \\
\text { High } †\end{array}$ & $\begin{array}{c}22.2(24 / 108) \\
31.5(131 / 416) \\
36.1(148 / 410) \\
\boldsymbol{P}=\mathbf{. 0 2}\end{array}$ & $\begin{array}{c}15.9(10 / 63) \\
15.4(44 / 286) \\
17.2(44 / 256) \\
P=.85\end{array}$ & $\begin{array}{c}30.6(19 / 62) \\
27.1(75 / 277) \\
29.3(71 / 242) \\
P=.78\end{array}$ \\
\hline
\end{tabular}

*AD according to UK-WP criteria.

†Low concentration of $E$ coli $\left(<9.35 \log _{10}\right.$ colony-forming units/g feces $)$.

$\$$ High concentration of $E$ coli $\left(\geq 9.35 \log _{10}\right.$ colony-forming units/g feces).

Boldface indicates statistically significant association (alpha $=.05$ ) 
TABLE E3. Parentally reported eczema: ORs for the association with $E$ coli colonization in the first month of life, stratified for $C D 14$ and TLR4 genotypes

\begin{tabular}{|c|c|c|c|c|c|c|}
\hline$T L R 4 / C D 14$ SNP & Genotype & No. & OR $(95 \% \mathrm{CI}) *$ & ORadj $(95 \% \mathrm{Cl}) \dagger$ & $P$ value for interaction§ & FDR-controlled $P$ value $\|$ \\
\hline$T L R 4$ c. -3612 & TT & 365 & $1.56(0.73-3.32)$ & $1.70(0.77-3.74)$ & .82 & 1.0 \\
\hline \multirow[t]{2}{*}{ (rs2770150) } & $\mathrm{CT}$ & 254 & $1.31(0.53-3.20)$ & $1.36(0.54-3.40)$ & & \\
\hline & $\mathrm{CC}$ & 43 & $2.33(0.23-23.00)$ & $1.64(0.10-28.05)$ & & \\
\hline \multirow[t]{2}{*}{$($ rs6478317) } & GA & 319 & $1.67(0.76-3.67)$ & $1.72(0.75-3.92)$ & & \\
\hline & GG & 75 & $1.71(0.18-16.27)$ & $1.35(0.12-15.57)$ & & \\
\hline TLR4 c. -1607 & TT & 478 & $1.33(0.70-2.53)$ & $1.35(0.69-2.62)$ & .42 & .96 \\
\hline TLR4 c. $93+3211$ & $\mathrm{CC}$ & 354 & $1.45(0.68-3.10)$ & $1.50(0.69-3.26)$ & .55 & .97 \\
\hline \multirow[t]{2}{*}{$(\operatorname{rs} 1927911)$} & $\mathrm{CT}$ & 257 & $1.72(0.71-4.16)$ & $2.15(0.84-5.53)$ & & \\
\hline & $\mathrm{TT} t$ & 42 & - & - & & \\
\hline$T L R 4$ c. $260+546$ & $\mathrm{CC}$ & 493 & $1.47(0.78-2.79)$ & $1.49(0.78-2.88)$ & .83 & 1.0 \\
\hline \multirow[t]{2}{*}{ (rs11536878) } & $\mathrm{CA}$ & 144 & $1.46(0.45-4.82)$ & $2.02(0.53-7.67)$ & & \\
\hline & $\mathrm{AA} \ddagger$ & 7 & - & - & & \\
\hline \multirow[t]{2}{*}{$(\mathrm{rs} 4986791)$} & $\mathrm{CT}$ & 90 & $1.31(0.53-3.20)$ & $0.99(0.16-6.27)$ & & \\
\hline & $\mathrm{TT} \ddagger$ & 4 & $2.33(0.23-23.00)$ & - & & \\
\hline TLR4 c. $3648+78$ & GG & 477 & $1.34(0.72-2.52)$ & $1.30(0.68-2.47)$ & .40 & 1.0 \\
\hline \multirow[t]{2}{*}{ (rs11536889) } & CG & 169 & $2.12(0.59-7.70)$ & $2.55(0.63-10.32)$ & & \\
\hline & $\mathrm{CC} \ddagger$ & 13 & - & - & & \\
\hline CD14/-1619 & TT\&CT & 540 & $1.65(0.89-3.04)$ & $1.79(0.95-3.35)$ & .34 & 1.0 \\
\hline (rs2915863) & $\mathrm{CC}$ & 108 & $0.89(0.22-3.58)$ & $0.71(0.15-3.42)$ & & \\
\hline CD14/-1145 & $\mathrm{TT} \& \mathrm{CT}$ & 503 & $1.67(0.88-3.14)$ & $1.89(0.98-3.65)$ & .41 & 1.0 \\
\hline (rs2569191) & $\mathrm{CC}$ & 155 & $1.15(0.35-3.75)$ & $1.20(0.34-4.29)$ & & \\
\hline$C D 14 /-550$ & $\mathrm{CC}$ & 373 & $1.69(0.78-3.67)$ & $1.74(0.79-3.85)$ & .92 & .97 \\
\hline \multirow[t]{2}{*}{ (rs5744455) } & $\mathrm{CT}$ & 238 & $1.77(0.72-4.36)$ & $2.32(0.86-6.27)$ & & \\
\hline & TT & 32 & $0.64(0.05-8.12)$ & $0.53(0.004-74.2)$ & & \\
\hline
\end{tabular}

*Unadjusted ORs (95\% CIs) for parentally reported eczema in E coli-colonized infants compared with uncolonized infants stratified for genotype.

†Adjusted ORs (95\% CIs); adjusted for parental and sibling's atopic history, recruitment group, sex, age at collection of feces, and pets.

\$Minor allele homozygotes excluded from analysis because of limited numbers.

$\S$ Likelihood ratio test for interaction (based on comparison of multivariate models with and without interaction term).

$\| P$ value controlled for FDR according to the Benjamini-Hochberg approach (based on a total of 39 tests for interaction).

Boldface indicates statistically significant associations (alpha $=.05$ ) 
TABLE E4. AD (according to UK-WP criteria): ORs for the association with E coli colonization in the first month of life, stratified for CD14 and TLR4 genotypes

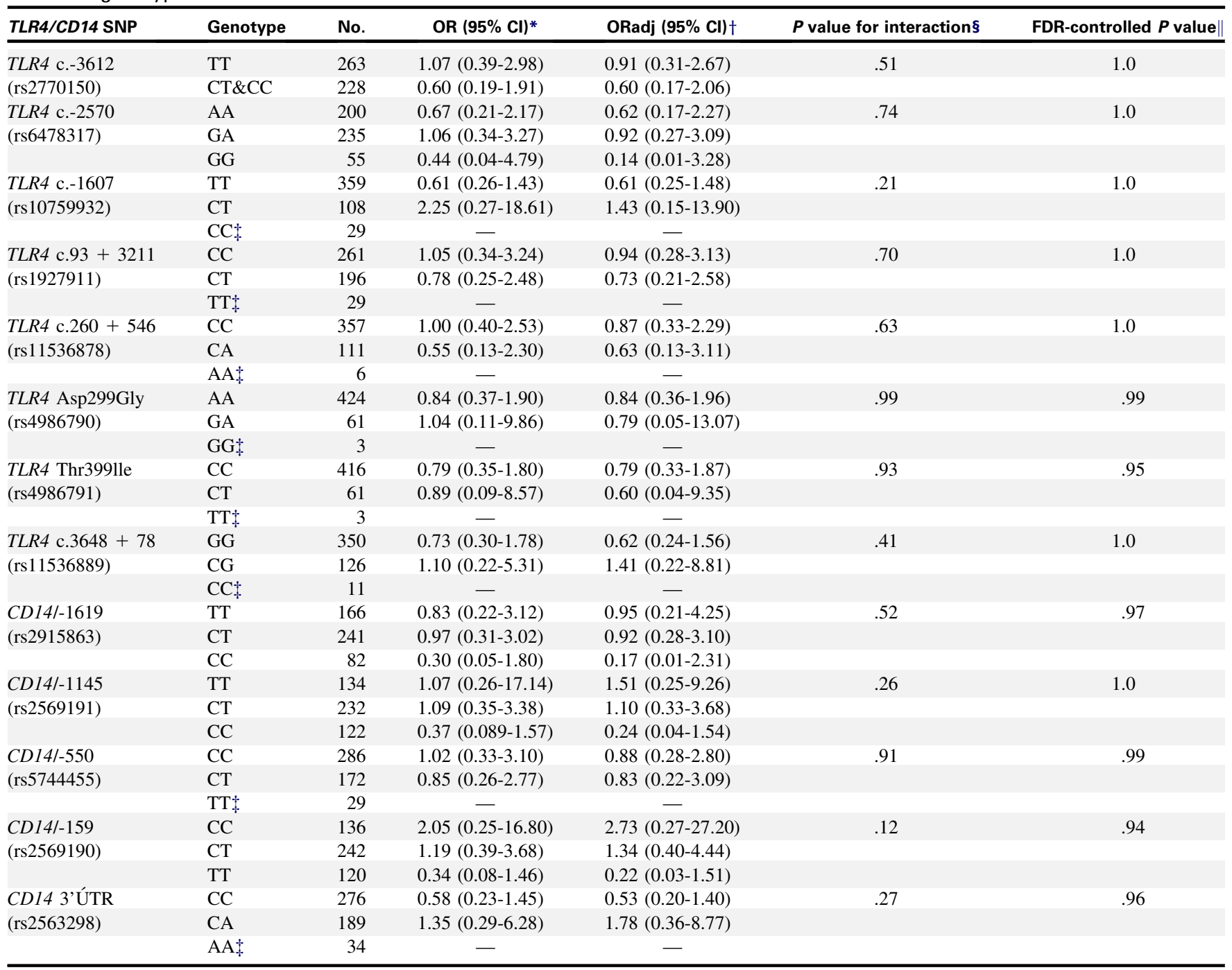

*Unadjusted ORs (95\% CIs) for AD in E coli-colonized infants compared with uncolonized infants, stratified for genotype.

$\dagger$ Adjusted ORs (95\% CIs); adjusted for parental and sibling's atopic history, recruitment group, sex, age at collection of feces, and pets.

†Minor allele homozygotes excluded from analysis because of limited numbers.

$\S$ Likelihood ratio test for interaction (based on comparison of multivariate models with and without interaction term).

$\| P$ value controlled for FDR according to the Benjamini-Hochberg approach (based on a total of 39 tests for interaction). 
TABLE E5. Allergic sensitization: ORs for the association with $E$ coli colonization in the first month of life, stratified for CD14 and TLR4 genotypes

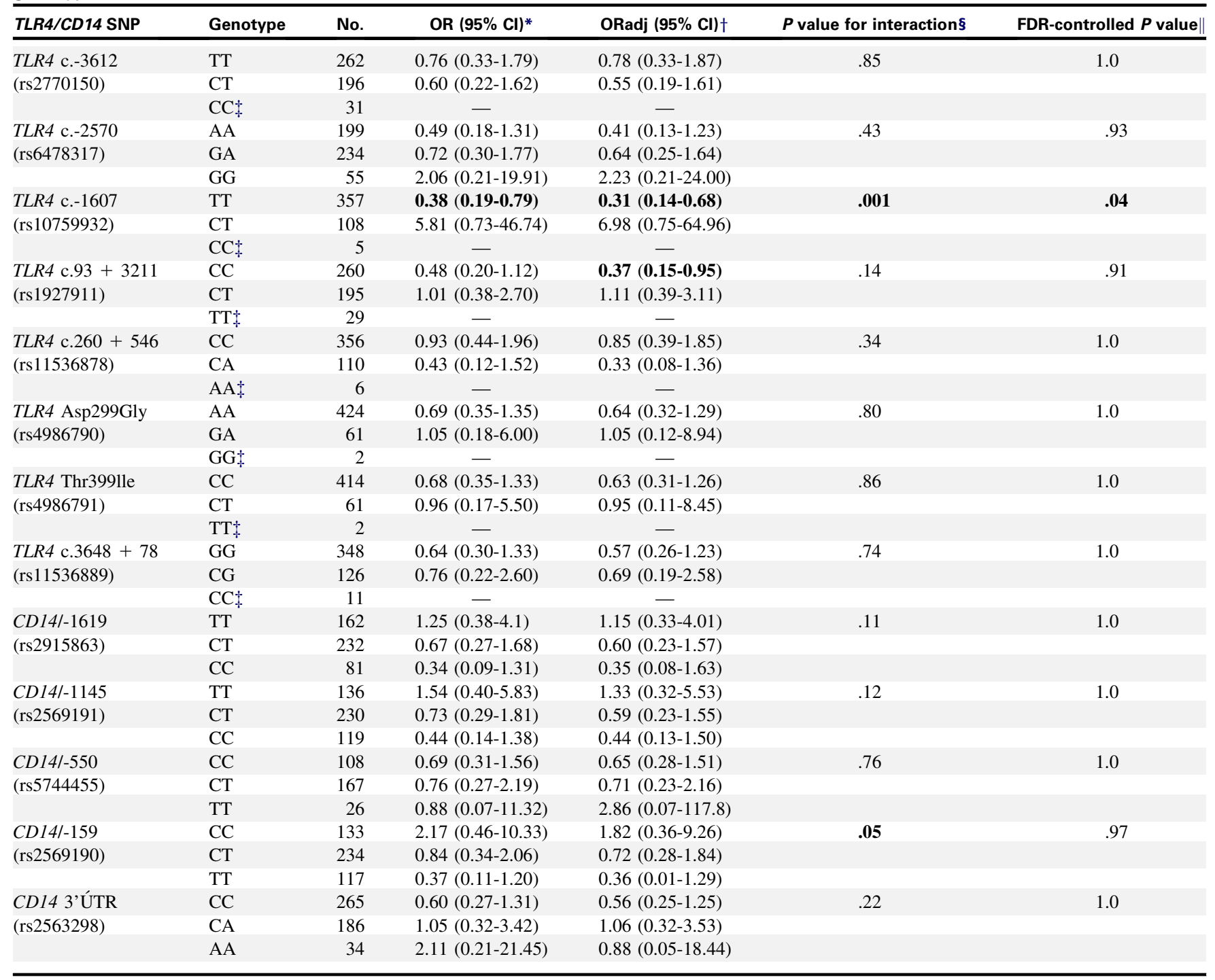

*Unadjusted ORs $(95 \% \mathrm{CIs})$ for allergic sensitization in $E$ coli-colonized infants compared with uncolonized infants, stratified for genotype.

$\dagger$ Adjusted ORs (95\% CIs); adjusted for parental and sibling's atopic history, recruitment group, sex, age at collection of feces, and pets.

$\$$ Minor allele homozygotes excluded from analysis because of limited numbers.

$\S$ Likelihood ratio test for interaction (based on comparison of multivariate models with and without interaction term).

$\| P$ value controlled for FDR according to the Benjamini-Hochberg approach (based on a total of 39 tests for interaction).

Boldface indicates statistically significant associations (alpha $=.05)$ 